\title{
Anatomical Changes and Audiological Profile in Branchio-oto-renal Syndrome: A Literature Review
}

\author{
Tâmara Andrade Lindau ${ }^{1}$ Ana Cláudia Vieira Cardoso ${ }^{1}$ Natalia Freitas Rossi ${ }^{1} \quad$ Célia Maria Giacheti $^{1}$ \\ ${ }^{1}$ Department of Speech Pathology, Universidade Estadual Paulista - \\ UNESP, Marília, São Paulo, Brazil \\ Int Arch Otorhinolaryngol 2014;18:68-76. \\ Address for correspondence Célia Maria Giacheti, PhD, Department of \\ Speech Pathology, Universidade Estadual Paulista UNESP, Av. Hygino \\ Muzzi Filho, 737, Marília, São Paulo 14525-900, Brazil \\ (e-mail: giacheti@uol.com.br).
}

\begin{abstract}
Introduction Branchio-oto-renal (BOR) syndrome is an autosomal-dominant genetic condition with high penetrance and variable expressivity, with an estimated prevalence of 1 in 40,000. Approximately $40 \%$ of the patients with the syndrome have mutations in the gene EYA1, located at chromosomal region $8 q 13.3$, and $5 \%$ have mutations in the gene SIX5 in chromosome region 19q13. The phenotype of this syndrome is characterized by preauricular fistulas; structural malformations of the external, middle, and inner ears; branchial fistulas; renal disorders; cleft palate; and variable type and degree of hearing loss.

Aim Hearing loss is part of BOR syndrome phenotype. The aim of this study was to present a literature review on the anatomical aspects and audiological profile of BOR syndrome.

\section{Keywords}

- branchio-oto-renal syndrome

- BOR syndrome

- hearing

- review

Data Synthesis Thirty-four studies were selected for analysis. Some aspects when specifying the phenotype of BOR syndrome are controversial, especially those issues related to the audiological profile in which there was variability on auditory standard, hearing loss progression, and type and degree of the hearing loss. Mixed loss was the most common type of hearing loss among the studies; however, there was no consensus among studies regarding the degree of the hearing loss.
\end{abstract}

\section{Introduction}

The etiology of hearing loss has been investigated in molecular and genetics medical centers. ${ }^{1}$ Anatomical and physiological changes in the auditory system have been described as part of the phenotype of numerous genetic syndromes, including the previously studied branchio-oto-renal (BOR) syndrome. $^{2}$

The features of this clinical condition were first described in 1864 when Heusinger presented the initial reports on the association between branchial fistulas, preauricular fistulas, and hearing loss. ${ }^{3}$ However, these features combined with auricular malformations and renal anomalies, thus comprising the phenotype of a specific condition, were described almost 110 years after the first clinical reports, and it was called BOR syndrome. ${ }^{4-6}$

Different classifications have been applied to this condition over the years, including Melnick-Fraser syndrome. This nomenclature originates from the first phenotype descriptions by these authors, "ear pits deafness syndrome" 7 and "branchio-oto-ureteral syndrome." 8 However, contemporary studies have adopted the term "BOR syndrome" in a systematic way.

The clinical characteristics that compose the BOR syndrome phenotype can be classified according to the occurrence of larger and smaller anomalies. The larger or more frequent anomalies are: (1) hearing loss (sensorineural, received

August 27, 2013

accepted

September 4, 2013
DOI http://dx.doi.org/

10.1055/s-0033-1358659.

ISSN 1809-9777.
Copyright $\odot 2014$ by Thieme Publicações License terms Ltda, Rio de Janeiro, Brazil

(c) $(1) \$$ 
conductive, or mixed), (2) preauricular pits, (3) renal anomalies ranging from mild hypoplasia to agenesis, (4) brachial fistulae, and (5) stenosis of the external auditory canal. The smaller or less frequent anomalies are: (1) lacrimal duct aplasia, (2) short or cleft palate, (3) retrognathia, (4) congenital hip dysplasia, (5) facial nerve paralysis, (6) gustatory lacrimation, and (7) pancreatic cyst. ${ }^{9}$

Such anomalies are used as criteria to diagnose BOR syndrome. In other words, the presence of three major deficiencies, or the combination of two major and two smaller anomalies, or the presence of a major anomaly associated with presence of another first degree family member diagnosed with the syndrome. ${ }^{10}$

One of the most mentioned characteristics as part of the BOR syndrome phenotype is progressive hearing loss, which can be mixed, conductive, or sensorineural and can range from mild to profound. ${ }^{9,11}$ In some patients, the hearing loss has a fluctuating pattern. ${ }^{12-15}$ Studies have reported the occurrence of congenital cholesteatoma among the less common characteristics. ${ }^{16-18}$

\section{Genetic/Etiologic Bases of Branchio-Oto-Renal Syndrome}

The estimated rate of BOR syndrome is $1: 40,000 .{ }^{4-6,9,19}$ BOR syndrome presents a pattern of autosomal-dominant inheritance and is considered the most common syndromic hearing loss form of genetic etiology with high penetrance and variable expressivity. ${ }^{4,8,19-21}$ In addition to the autosomaldominant, mitochondrial inheritance, ${ }^{22}$ some patients present with "new" mutations. ${ }^{7,23}$ Deletions of various sizes have been found in individuals with BOR syndrome. ${ }^{24-26}$

The first chromosomal region associated with the syndrome was $8 q 12-22$, identified from linkage studies in families that had multiple members affected. ${ }^{27}$ Subsequently, the detailed genetic study of this region allowed researchers to determine the chromosomal region 8q13.3 was associated with the syndrome. ${ }^{24}$ The EYA1 gene, which is responsible for the development of the branchial arches, auditory system, and kidneys, is located in this region. ${ }^{25,28}$

EYA1 gene mutations have been reported in most cases of BOR syndrome. ${ }^{2,29}$ However, studies described that in many cases of clinically diagnosed BOR syndrome, the screening for alterations in the EYA1 gene was negative, which also showed that other genes are involved in the BOR syndrome etiology, indicating a condition with genetic heterogeneity. ${ }^{10,30,31}$

Missense mutations and small deletions in the SIX1 gene, located on chromosome region 14q23.1, were also reported by several studies that described families affected by BOR syndrome. ${ }^{28,32-36}$ However, intrafamilial phenotypic variability can be observed in all families studied that showed mutations in SIX1.22

\section{General Clinical Features of Branchio-Oto-Renal Syndrome}

Based on the reviewed studies, the most common triad of BOR syndrome findings is: (1) hearing loss and preauricular fistulas located near the helix, (2) branchial fistulas typically found on the anterior border of the sternocleidomastoid muscle, and (3) a variability of renal anomalies, which often present no symptoms. Branchial fistulas are usually located next to the first branchial arch. However, a rare case was described where the subject had four branchial fistulas located at the first and second branchial arches. ${ }^{37,38}$

A retrospective analysis of seven individuals diagnosed with BOR syndrome has shown that besides the applicant phenotype, other clinical features were found in these individuals, such as gustatory lacrimation, imperforate anus, otosclerosis, and congenital vocal cord paresis. ${ }^{39}$

The manifestations of BOR syndrome can also be composed of craniofacial abnormalities such as microcephaly, ${ }^{39}$ hemifacial microsomy, ${ }^{40}$ long face syndrome associated with lacrimal duct stenosis, ${ }^{5,7,14,17,41,42}$ overbite palate, ${ }^{17}$ and retrognathia. ${ }^{39}$ The presence of micrognathia, ${ }^{43}$ hypodontia, ${ }^{39}$ and microdontia associated with malformations of permanent molars ${ }^{44}$ were also reported. Lacrimal duct stenosis, although rare, has been described in some studies, ${ }^{6,7}$ and its occurrence is associated with gustatory lacrimation. ${ }^{39,41}$

One study described the presence of cardiac manifestation -mitral valve prolapse-in a family diagnosed with BOR syndrome (one family member had tachycardia). These symptoms were not reported in previous studies. This manifestation was identified in five of seven patients with BOR syndrome in this family, whereas hearing loss was present in all of them. Other previously described features such as branchial fistula, preauricular appendices, external ear malformation, renal anomalies, and anomalies of the lacrimal duct were found in this family. ${ }^{45}$

Limited kidney functions, bifid renal pelvis, hypoplasia, and renal cysts associated with urinary tract infections appeared in one study. ${ }^{20}$ Another study reported that such infections and glomerulonephritis episodes may be associated with normal renal anatomy and physiology. ${ }^{16}$ However, a case with a bifid kidney, double ureter, and vesicoureteric reflux ${ }^{46}$ as well as two patients who reported congenital hydronephrosis were described. ${ }^{40}$ Only one case has been described with severe reduction in kidney volume without family history of this condition, ${ }^{47}$ and there was another case with renal agenesis. ${ }^{48}$

From 1975 to 2013, several authors have described specific phenotypes in individuals diagnosed with BOR syndrome: these articles are summarized in - Table 1. Most of these studies describe isolated patients or a familial nucleus and show varied expressiveness.

Hearing loss is part of the BOR syndrome phenotype. The aim of this study was to present a literature review on the anatomical aspects and audiological profile in this condition.

\section{Methods}

This study review published studies describing BOR syndrome from 1975 to 2013. Research was performed on the following national and international databases: BIREME (Virtual Health Library-LILACS and IBECS) PubMed/MEDLINE (MEDlars onLINE), ProQuest, Web of Science (integrated into ISI Web of Knowledge), and OMIM (Online Mendelian Inheritance in Man). 
Table 1 Description of general findings from BOR syndrome

\begin{tabular}{|l|}
\hline Branchial anomalies \\
Branchial fistulae (first/second arches) \\
Other anomalies \\
Lacrimal duct aplasia/gustatory lacrimation \\
Palate abnormality (short/cleft) \\
Micrognathia/retrognathia \\
Facial asymmetry \\
Preauricular pits \\
Small ears and low implantation \\
Pinnae deformities \\
Facial nerve paresis \\
Microdontia/hypodontia \\
Congenital vocal cord paresis \\
Congenital hip dysplasia \\
Pancreatic duplication cyst \\
Mitral valve prolapse \\
Renal anomalies \\
Ureteral pelvic junction obstruction \\
Renal cyst \\
Renal agenesis \\
Renal hypoplasia \\
Renal aplasia \\
Double ureter
\end{tabular}

Abbreviation: BOR, branchio-oto-renal.

The following research descriptors were used according to the criteria of the MeSH:

1. "Branchio-Otorrenal Syndrome" and "Hearing Loss" or "Hearing Disorders"

2. "Branchio-Oto-Renal Syndrome" and ("Hearing" or "Hearing Disorders" or "Hearing Loss")

3. "Branchio-Oto-Renal Syndrome"

\section{Exclusion Criteria}

This review refers to the auditory aspects of BOR syndrome and used the following criteria for the exclusion of articles: the title and summary were not related to the purpose of the review; repeated articles and articles written in languages other than English, Portuguese, or Spanish; animal studies; editorial letters, review articles, and articles in which BOR syndrome was associated with other syndromes or genetic conditions with partial phenotype of BOR syndrome; articles that cited BOR syndrome as a cause of loss of hearing; and those that were focused only on general and genetic aspects of BOR syndrome.

From the BIREME database (LILACS and IBECS) and ProQuest, six articles were found using research descriptor 1, and five articles were excluded based on the exclusion criteria. When searching the MEDLINE database, via PubMed, using research descriptor 2, 37 articles were found, 27 of which were excluded by the criteria mentioned above, and thus 10 articles remained. The last search was performed on the Web of Science database using research descriptor 3. It resulted in 96 articles, 73 of which were excluded considering the exclusion criteria, leaving 23 remaining articles.

The results concerning literature review and discussion followed the chronological order of publication, and the issues were grouped by the descriptors used in the literature.
-Fig. 1 shows the flow diagram that demonstrates the articles' selection criteria.

\section{Literature Review}

After the application of the exclusion criteria, 34 studies were selected and compiled on $\boldsymbol{-}$ Table $\mathbf{2}$, which contains the year of publication, article title, author, and number of the study participants.

\section{Results}

\section{Anatomical Changes and Audiological Profile}

In the studies reviewed, a prevalence of mixed hearing loss was observed, followed by conductive and sensorineural hearing loss. Some studies reported that the presence of chronic or recurrent otitis media is an aggravating factor for hearing loss, which may be associated with ossicular chain malformations or alterations, or presence of cleft palate, increasing the number with conductive/mixed hearing loss. ${ }^{6,16,20,49-51}$ There was a higher recurrence of moderate and severe hearing loss among the studies' participants, probably due to the number of abnormalities found in the inner ear, which encompasses cochlear alterations to malformation of the vestibular system.

Some research verified that in addition to the auditory standards mentioned above, hearing loss could maintain a progressive and/or fluctuating pattern, ${ }^{6,13-15,19,46,52}$ which contradicts other studies that related their standard as stable. ${ }^{12,16,19,53}$ A retrospective study identified significant hearing loss progression in 10 patients. The results demonstrated that in seven patients, the hearing loss was fluctuating; however, this fluctuation was only significant in young patients. ${ }^{52} \mathrm{~A}$ study reported that patients with an enlarged endolymphatic sac or duct had hearing thresholds significantly higher than in those patients without such abnormalities, ${ }^{52}$ which corroborates the study of Kemperman et al, 2001. ${ }^{13}$

In the literature, a description was found of three patients with BOR syndrome who also had cholesteatoma. In one of them, the cholesteatoma was in the temporal bone cavity, bilaterally, and showed no association with the facial nerve alterations. However, the other patients showed facial nerve alterations. One subject had facial nerve paralysis on the left side and in the other subject had right-side paralysis. ${ }^{16-18,54}$

Cochlear implant in BOR syndrome was first used in a 3 -year-old with congenital profound hearing loss and impaired language and speech development. Radiologic evaluation of the temporal bone and the inner ear showed severe dysplasia of the vestibule, ossicles, and bilaterally malformed semicircular canals and facial nerve posteriorly positioned. Three weeks after implantation, initial mapping showed positive responses. After hearing habilitation, the patient was able to recognize speech stimuli in a closed set. $^{55}$

Radiologic studies and magnetic resonance imaging of the mastoid and middle ear showed several types of middle and inner ear pathology, among them: (1) hypoplasia, 


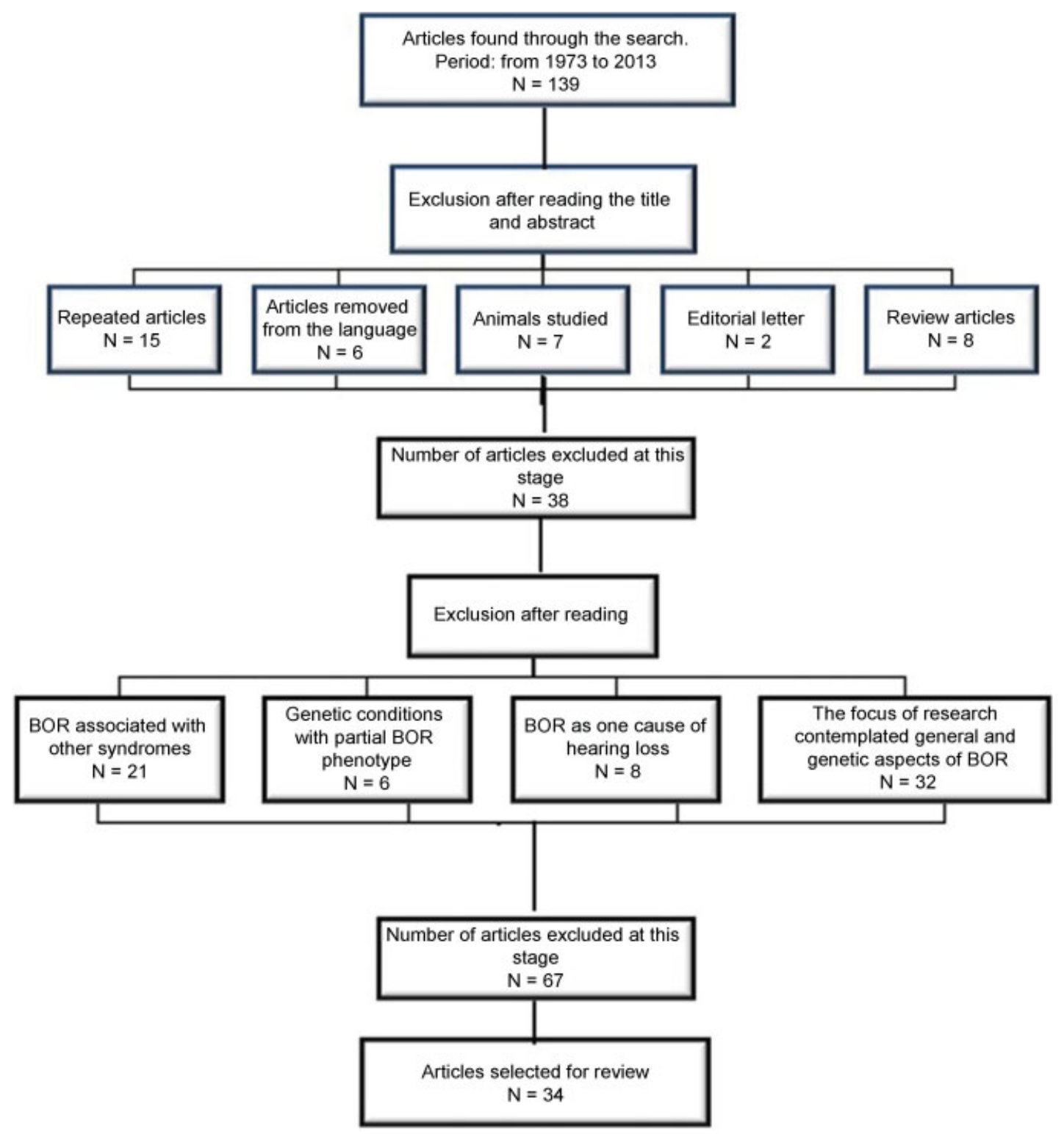

Fig. 1 Flowchart demonstrating the process of deleting articles. Abbreviation: BOR, branchio-oto-renal syndrome.

malformation and displacement of the ossicular chain, such as the junction of the hammer and anvil fixing the malleus in the tympanic membrane, and calcified oval window; (2) malformations-enlargement-and asymmetry of the semicircular canals/ducts and endolymphatic sac; and (3) cochlear hypoplasia or dysplasia. 6,7,14,49,50,53,56-58

A study retrospectively assessed tomographic findings of 21 subjects (42 ears) with a clinical diagnosis of BOR syndrome, based on criteria derived from genotype and phenotype, and described the most common and easily identifiable features of BOR syndrome by visual inspection. The results of this assessment were: (1) apical cochlear hypoplasia was present in all individuals with BOR syndrome and no subject had normal hearing, (2) the facial nerve was diverted to the medial side of the cochlea in 38 of 42 ears, and ( 3 ) the inner ear channel was funnel-shaped in 36 of the 42 ears. $^{59}$

\section{Discussion}

The phenotypic features related to the most-mentioned anatomical ear alterations in BOR syndrome were: malformation; hyperplasia and low implantation of the ear; narrowing of the external acoustic meatus; ossicular chain abnormalities; reduced size of the middle ear cavity; otosclerosis; semicircular canal anomalies involving hypoplasia, dysplasia, and enlargement of the endolymphatic duct and sac; and cochlear hypoplasia.

The audiological profile, considering the type and degree of hearing loss and the association of the auditory system characteristics, is presented in - Table $\mathbf{3}$.

The analysis of these studies showed that there was a high frequency of mixed hearing loss (33.72\%) followed by sensorineural (10.98\%) and conductive hearing loss (7.84\%); however, in $47.45 \%$ of the articles, this information was not 
72 Anatomical Changes in Branchio-oto-renal Syndrome Lindau et al.

Table 2 Summary of the reviewed articles' information

\begin{tabular}{|c|c|c|c|c|}
\hline Article & Title & Author & Year & Sample \\
\hline 1 & $\begin{array}{l}\text { Familial branchio-oto-renal dysplasia: a new } \\
\text { addition to the branchial arch syndromes. }\end{array}$ & Melnick et al ${ }^{5}$ & 1976 & $n=4$ (two generations) \\
\hline 2 & $\begin{array}{l}\text { Genetic aspects of the BOR syndrome- } \\
\text { branchial fistulas, ear pits, hearing loss, and } \\
\text { renal anomalies }\end{array}$ & Fraser et al ${ }^{6}$ & 1978 & $n=8$ (three generations) \\
\hline $3^{a}$ & $\begin{array}{l}\text { The earpits-deafness syndrome. Clinical and } \\
\text { genetic aspects }\end{array}$ & $\begin{array}{l}\text { Cremers, Fikkers-Van } \\
\text { Noord }^{7}\end{array}$ & 1980 & $n=19$ (four families) \\
\hline 4 & $\begin{array}{l}\text { Temporal bone findings in a family with } \\
\text { branchio-oto-renal syndrome (BOR) }\end{array}$ & Ostri et al ${ }^{12}$ & 1991 & $n=19$ (four generations) \\
\hline 5 & $\begin{array}{l}\text { Branchio-oto-renal (BOR) syndrome: variable } \\
\text { expressivity in a five-generation pedigree }\end{array}$ & König et $\mathrm{al}^{20}$ & 1994 & $n=6$ (four generations) \\
\hline 6 & $\begin{array}{l}\text { Phenotypic manifestations of branchio-oto- } \\
\text { renal syndrome }\end{array}$ & Chen et $\mathrm{al}^{19}$ & 1995 & $n=32$ \\
\hline 7 & Branchio-oto-renal syndrome & Millman et $\mathrm{al}^{38}$ & 1995 & $n=1$ \\
\hline 8 & $\begin{array}{l}\text { Renal failure and deafness: branchio-oto-re- } \\
\text { nal syndrome }\end{array}$ & Misra, Nolph ${ }^{43}$ & 1998 & $n=1$ \\
\hline 9 & $\begin{array}{l}\text { Congenital cholesteatoma and malforma- } \\
\text { tions of the facial nerve: rare manifestations } \\
\text { of the BOR syndrome }\end{array}$ & Graham et al ${ }^{16}$ & 1999 & $n=2$ \\
\hline 10 & New' manifestations of BOR syndrome & Weber, Kousseff ${ }^{39}$ & 1999 & $n=7$ \\
\hline 11 & $\begin{array}{l}\text { Bilateral congenital cholesteatoma in bran- } \\
\text { chio-oto-renal syndrome }\end{array}$ & Worley et al ${ }^{17}$ & 1999 & $n=1$ \\
\hline 12 & $\begin{array}{l}\text { Branchio-oto-renal syndrome with general- } \\
\text { ized microdontia }\end{array}$ & Prabhu et al ${ }^{44}$ & 1999 & $n=1$ \\
\hline 13 & $\begin{array}{l}\text { EYA1 nonsense mutation in a Japanese } \\
\text { branchio-oto-renal syndrome family }\end{array}$ & Usami et $\mathrm{al}^{54}$ & 1999 & $n=3$ (two generations) \\
\hline 14 & $\begin{array}{l}\text { Temporal bone computed tomography } \\
\text { findings in bilateral sensorineural hearing } \\
\text { loss }\end{array}$ & Bamiou et al $^{55}$ & 2000 & $n=3$ \\
\hline 15 & $\begin{array}{l}\text { Branchio-oto-renal syndrome: a report on } \\
\text { nine family groups }\end{array}$ & Bellini et al ${ }^{42}$ & 2001 & $n=10$ (nine families) \\
\hline 16 & $\begin{array}{l}\text { The presence of a widened vestibular aque- } \\
\text { duct and progressive sensorineural hearing } \\
\text { loss in the branchio-oto-renal syndrome. A } \\
\text { family study }\end{array}$ & Stinckens et $\mathrm{al}^{14}$ & 2001 & $n=12$ \\
\hline 17 & $\begin{array}{l}\text { Progressive fluctuant hearing loss, enlarged } \\
\text { vestibular aqueduct, and cochlear hypopla- } \\
\text { sia in branchio-oto-renal syndrome }\end{array}$ & Kemperman et al ${ }^{13}$ & 2001 & $n=2$ (two generations) \\
\hline 18 & $\begin{array}{l}\text { Visualization of inner ear dysplasias in pa- } \\
\text { tients with sensorineural hearing loss }\end{array}$ & Klingebiel et al ${ }^{57}$ & 2001 & $n=2$ \\
\hline 19 & $\begin{array}{l}\text { Inner ear anomalies are frequent but non- } \\
\text { obligatory features of the branchio-oto-renal } \\
\text { syndrome }\end{array}$ & Kemperman et al ${ }^{58}$ & 2002 & $n=35$ (six families) \\
\hline 20 & $\begin{array}{l}\text { A family with the branchio-oto-renal syn- } \\
\text { drome: clinical and genetic correlations }\end{array}$ & Pierides et al ${ }^{46}$ & 2002 & $n=10$ (two generations) \\
\hline 21 & $\begin{array}{l}\text { Temporal bone anomalies in the branchio- } \\
\text { oto-renal syndrome: detailed computed to- } \\
\text { mographic and magnetic resonance imaging } \\
\text { findings }\end{array}$ & Ceruti et al ${ }^{15}$ & 2002 & $n=8$ (four generations) \\
\hline 22 & $\begin{array}{l}\text { Síndrome branquio-oto-renal y colesteatoma } \\
\text { congénito }\end{array}$ & Adiego et al ${ }^{18}$ & 2003 & $n=1$ \\
\hline
\end{tabular}


Table 2 (Continued)

\begin{tabular}{|c|c|c|c|c|}
\hline Article & Title & Author & Year & Sample \\
\hline 23 & $\begin{array}{l}\text { Evidence of progression and fluctuation of } \\
\text { hearing impairment in branchio-oto-renal } \\
\text { syndrome }\end{array}$ & Kemperman et al 53 & 2004 & $n=32$ (six families) \\
\hline 24 & $\begin{array}{l}\text { Temporal bone findings on computed to- } \\
\text { mography imaging in branchio-oto-renal } \\
\text { syndrome }\end{array}$ & Propst et $\mathrm{al}^{59}$ & 2005 & $n=21$ \\
\hline $25^{a}$ & $\begin{array}{l}\text { Non-inherited manifestation of bilateral } \\
\text { branchial fistulae, bilateral pre-auricular si- } \\
\text { nuses and bilateral hearing loss: a variant of } \\
\text { branchio-oto-renal syndrome }\end{array}$ & Rana et $\mathrm{al}^{23}$ & 2005 & $n=1$ \\
\hline 26 & $\begin{array}{l}\text { Identification of a novel mutation in the EYA1 } \\
\text { gene in a Korean family with branchio-oto- } \\
\text { renal (BOR) syndrome }\end{array}$ & Kim et al ${ }^{49}$ & 2005 & $n=2$ (two generations) \\
\hline 27 & $\begin{array}{l}\text { Cochlear implantation in branchio-oto-renal } \\
\text { syndrome-a surgical challenge }\end{array}$ & Kameswaran et al ${ }^{56}$ & 2007 & $n=1$ \\
\hline 28 & Branchio-oto-renal syndrome & Garg et $\mathrm{al}^{47}$ & 2008 & $n=1$ \\
\hline 29 & $\begin{array}{l}\text { Achados genéticos, audiológicos e da lin- } \\
\text { guagem oral de um núcleo familial com } \\
\text { diagnóstico da síndrome Branquio-oto-renal } \\
\text { (SBOR) }\end{array}$ & Furlan et al ${ }^{51}$ & 2008 & $n=7$ (two generations) \\
\hline 30 & $\begin{array}{l}\text { From a branchial fistula to a branchiootore- } \\
\text { nal syndrome: a case report and review of } \\
\text { the literature }\end{array}$ & Senel et al ${ }^{50}$ & 2009 & $n=1$ \\
\hline 31 & $\begin{array}{l}\text { Mitral valve prolapse as a new finding in } \\
\text { branchio-oto-renal syndrome }\end{array}$ & Ayçiçek et al ${ }^{45}$ & 2010 & $n=1$ \\
\hline 32 & $\begin{array}{l}\text { Diagnostic and surgical challenge: middle } \\
\text { ear dermoid cyst in } 12 \text { month old with } \\
\text { branchio-oto-renal syndrome and multiple } \\
\text { middle-ear congenital anomalies }\end{array}$ & Johnston et al ${ }^{40}$ & 2011 & $n=1$ \\
\hline 33 & $\begin{array}{l}\text { Young woman with branchio-oto-renal syn- } \\
\text { drome and a novel mutation in the EYA-1 } \\
\text { gene }\end{array}$ & Nardi et al ${ }^{48}$ & 2011 & $n=1$ \\
\hline 34 & $\begin{array}{l}\text { Congenital unilateral facial nerve palsy as an } \\
\text { unusual presentation of BOR syndrome }\end{array}$ & $\begin{array}{l}\text { Jankauskienè, } \\
\text { Azukaitis }\end{array}$ & 2013 & $n=1$ \\
\hline
\end{tabular}

${ }^{\text {a }}$ Syndrome manifestation as a noninherited characteristic.

present. The degree of hearing loss was classified as moderate in $12.94 \%$ of the articles, mild in $6.66 \%$, severe in $6.27 \%$, and profound in $4.73 \%$. This information was not present in $67.84 \%$ of the articles. Only $29.4 \%$ of the studies described the hearing loss pattern, which was classified as stable, progressive, or fluctuating.

\section{Conclusion}

Because hearing loss is mentioned in a great number of BOR syndrome studies. Deafness linked to preauricular fistula, branchial fistulae, and renal anomalies should be investigated and monitored by a multidisciplinary team, mainly otorhinolaryngologic professionals.

Due to the variable phenotypic expression described, many cases of BOR syndrome may have been underdiagnosed, and sometimes the diagnosis is delayed, even in cases where the hearing impairment is severe and interferes with the development of language and speech.

This review shows that some aspects remain controversial due to syndrome variability and the difficulty of early diagnosis, especially in issues related to the audiological profile where there is a great variability in the auditory pattern and the hearing loss progression, type, and degree. Most studies described that mixed hearing loss is the most common type; however, there is no consensus about the degree.

In the 40 years of research on BOR syndrome, studies were aimed at characterization of the phenotype of this syndrome, and the hearing loss was mentioned as part of the phenotype; however, few specific studies characterize the hearing loss standard, type, and degree. 
74 Anatomical Changes in Branchio-oto-renal Syndrome Lindau et al.

Table 3 Auditory system characteristics and description of hearing loss in BOR syndrome

\begin{tabular}{|c|c|c|c|c|}
\hline Article & Type & Degree & Pattern & $\begin{array}{l}\text { Anatomic changes: external, middle, } \\
\text { and inner ear }\end{array}$ \\
\hline Melnick et $\mathrm{al}^{5}$ & Mixed & - & - & $\begin{array}{l}\text { Mondini-type cochlear malformation and } \\
\text { stapes fixation }\end{array}$ \\
\hline Fraser et al ${ }^{6}$ & Conductive/mixed & Mild to severe & Progressive & OC changes, ME fluid, otosclerosis \\
\hline $\begin{array}{l}\text { Cremers, Fikkers- } \\
\text { Van Noord }\end{array}$ & $\begin{array}{l}\text { Conductive/mixed/ } \\
\text { sensorineural }\end{array}$ & - & - & $\begin{array}{l}\text { Cochlear hypoplasia/dysplasia, narrow or } \\
\text { wide internal auditory canal, OC anoma- } \\
\text { lies, horizontal SC with reduced size }\end{array}$ \\
\hline Ostri et al ${ }^{12}$ & Mixed & $\begin{array}{l}\text { Moderate to } \\
\text { severe }\end{array}$ & Stable & $\begin{array}{l}\text { Cochlear hypoplasia, SC hypoplasia and } \\
\text { abnormal duct endolymphatic, massive } \\
\text { OC and reduced size of ME }\end{array}$ \\
\hline König et $\mathrm{al}^{20}$ & Mixed & Severe & - & Malformation of OC \\
\hline Chen et al ${ }^{19}$ & $\begin{array}{l}\text { Conductive/mixed/ } \\
\text { sensorineural }\end{array}$ & Mild to profound & $\begin{array}{l}\text { Progressive/ } \\
\text { stable }\end{array}$ & $\begin{array}{l}\text { Stenosis of the EEC, malformation of OC, } \\
\text { cochlear hypoplasia/dysplasia and en- } \\
\text { largement of the endolymphatic duct }\end{array}$ \\
\hline Millman et $\mathrm{al}^{38}$ & - & Severe & - & - \\
\hline Misra, Nolph ${ }^{43}$ & Mixed & $\begin{array}{l}\text { Moderate to } \\
\text { severe }\end{array}$ & - & Changes in $\mathrm{OC}$ \\
\hline Graham et al $^{16}$ & Conductive & Moderate & Stable & $\begin{array}{l}\text { Cholesteatoma, absence or abnormality } \\
\text { of the ossicles and oval window, TM } \\
\text { retraction }\end{array}$ \\
\hline Weber, Kousseff ${ }^{39}$ & $\begin{array}{l}\text { Conductive/ } \\
\text { sensorineural }\end{array}$ & Mild to moderate & - & Otosclerosis \\
\hline Worley et al ${ }^{17}$ & Mixed & Moderate & - & $\begin{array}{l}\text { Cholesteatoma, OC anomalies, otitis me- } \\
\text { dia-ventilation tubes }\end{array}$ \\
\hline Prabhu et al ${ }^{44}$ & Mixed & - & - & $\begin{array}{l}\text { Malformed and hyperplastic right pinna } \\
\text { and a preauricular pit on the left ear }\end{array}$ \\
\hline Usami et $\mathrm{al}^{54}$ & Conductive/mixed & Mild to moderate & Stable & $\begin{array}{l}\text { Cochlear hypoplasia of the lateral and } \\
\text { posterior semicircular canal, abnormal } \\
\text { OC, soft mass density in the epitympanic } \\
\text { and mastoid cavity }\end{array}$ \\
\hline Bamiou et al $^{55}$ & - & - & - & Mondini-type cochlear malformation \\
\hline Bellini et al $^{42}$ & $\begin{array}{l}\text { Conductive/mixed/ } \\
\text { sensorineural }\end{array}$ & - & - & - \\
\hline Stinckens et al ${ }^{14}$ & Sensorineural & - & Progressive & $\begin{array}{l}\text { Enlarged vestibular aqueduct, cochlear } \\
\text { hypoplasia }\end{array}$ \\
\hline Kemperman et al ${ }^{13}$ & Sensorineural & Profound & $\begin{array}{l}\text { Progressive/ } \\
\text { fluctuant }\end{array}$ & $\begin{array}{l}\text { Cochlear hypoplasia, enlarged vestibular } \\
\text { aqueduct }\end{array}$ \\
\hline Klingebiel et $\mathrm{al}^{57}$ & - & - & - & $\begin{array}{l}\text { Dysplasia of the SC superior, cochlear } \\
\text { hypoplasia ( } 1.5 \text { turn) }\end{array}$ \\
\hline Kemperman et al ${ }^{58}$ & - & - & - & $\begin{array}{l}\text { Enlarged vestibular aqueduct, hypoplastic } \\
\text { cochleae and labyrinths, malformed } \\
\text { auricles }\end{array}$ \\
\hline Pierides et al ${ }^{46}$ & - & - & Progressive & - \\
\hline Ceruti et al ${ }^{15}$ & Sensorineural & - & Progressive & $\begin{array}{l}\text { Cochlear hypoplasia/dysplasia, SC mal- } \\
\text { formations, OC malformations }\end{array}$ \\
\hline Adiego et al ${ }^{18}$ & Mixed & Moderate & - & $\begin{array}{l}\text { EEC stenosis, cholesteatoma, OC malfor- } \\
\text { mation, cochlear hypoplasia, abnormal } \\
\text { morphology of the SC }\end{array}$ \\
\hline Kemperman et al ${ }^{53}$ & - & - & $\begin{array}{l}\text { Progressive/ } \\
\text { fluctuant }\end{array}$ & $\begin{array}{l}\text { Enlarged vestibular aqueduct, medial de- } \\
\text { viation of facial nerve, cochlear hypoplasia }\end{array}$ \\
\hline Propst et al ${ }^{59}$ & - & - & - & $\begin{array}{l}\text { Cochlear hypoplasia, narrowed internal } \\
\text { auditory canal }\end{array}$ \\
\hline
\end{tabular}


Table 3 (Continued)

\begin{tabular}{|c|c|c|c|c|}
\hline Article & Type & Degree & Pattern & $\begin{array}{l}\text { Anatomic changes: external, middle, } \\
\text { and inner ear }\end{array}$ \\
\hline Rana et $a^{23}$ & - & - & - & $\begin{array}{l}\text { Pneumatic temporal bone, partial agen- } \\
\text { esis of the EEC }\end{array}$ \\
\hline Kim et $\mathrm{al}^{49}$ & Mixed & $\begin{array}{l}\text { Moderate to } \\
\text { profound }\end{array}$ & - & $\begin{array}{l}\text { EEC stenosis, dense mass in the mastoid } \\
\text { and tympanic cavity, cochlear hypoplasia, } \\
\text { enlarged vestibular aqueduct, OC mal- } \\
\text { formation, otitis media }\end{array}$ \\
\hline Kameswaran et al ${ }^{56}$ & Sensorineural & Profound & - & $\begin{array}{l}\text { Vestibular dysplasia, SC and ossicles } \\
\text { malformation }\end{array}$ \\
\hline Garg et $\mathrm{al}^{47}$ & - & $\begin{array}{l}\text { Moderate to } \\
\text { profound }\end{array}$ & - & - \\
\hline Furlan et $\mathrm{al}^{51}$ & Conductive/mixed & $\begin{array}{l}\text { Mild to moderate } \\
\text { to severe }\end{array}$ & - & - \\
\hline Senel et al $^{50}$ & Conductive/mixed & Mild to moderate & - & $\begin{array}{l}\text { EEC stenosis, auricular malformation, co- } \\
\text { chlear and SC hypoplasia, OC } \\
\text { malformation }\end{array}$ \\
\hline Ayçiçek et al ${ }^{45}$ & - & - & - & EE and IE malformation \\
\hline Johnston et $\mathrm{al}^{40}$ & Mixed & $\begin{array}{l}\text { Moderate to } \\
\text { severe }\end{array}$ & - & $\begin{array}{l}\text { Cochlear hypoplasia, OC malformation, } \\
\text { enlarged vestibular aqueduct }\end{array}$ \\
\hline Nardi et al ${ }^{48}$ & - & - & - & Enlarged vestibular aqueduct \\
\hline $\begin{array}{l}\text { Jankauskienè, } \\
\text { Azukaitis }\end{array}$ & - & - & - & $\begin{array}{l}\text { Uncertain results of otoacoustic emission } \\
\text { and facial nerve paralysis at the RE }\end{array}$ \\
\hline
\end{tabular}

Abbreviations: EE, external ear; EEC, external ear canal; IE, inner ear; ME, middle ear; OC, ossicular chain; RE, right ear; SC, semicircular canals; TM, tympanic membrane.

\section{References}

1 Ramos PZ, de Moraes VCS, Svidnicki MCCM, Soki MN, Castilho AM, Sartorato EL. Etiologic and diagnostic evaluation: algorithm for severe to profound sensorineural hearing loss in Brazil. Int J Audiol 2013:1-7

2 Kniffin CL. Branchiootorenal syndrome 1; BOR1. OMIM 2012. Available at: http://omim.org/entry/113650. Access date: 10/07/ 2013.

3 Heusinger CF. Hals-Kiemen-Fisteln von noch nicht beobachteter form. Virchows. Arch Path Anat 1864;29:338-380

4 Melnick M, Bixler D, Silk K, Yune H, Nance WE. Autosomal dominant branchiootorenal dysplasia. Birth Defects Orig Artic Ser 1975;11:121-128

5 Melnick M, Bixler D, Nance WE, Silk K, Yune H. Familial branchiooto-renal dysplasia: a new addition to the branchial arch syndromes. Clin Genet 1976;9:25-34

6 Fraser FC, Ling D, Clogg D, Nogrady B. Genetic aspects of the BOR syndrome-branchial fistulas, ear pits, hearing loss, and renal anomalies. Am J Med Genet 1978;2:241-252

7 Cremers CW, Fikkers-Van Noord M. The earpits-deafness syndrome. Clinical and genetic aspects. Int J Pediatr Otorhinolaryngol 1980;2:309-322

8 Fraser FC, Aymé S, Halal F, Sproule J. Autosomal dominant duplication of the renal collecting system, hearing loss, and external ear anomalies: a new syndrome? Am J Med Genet 1983;14:473-478

9 Smith RJH, Schwartz C. Branchio-oto-renal syndrome. J Commun Disord 1998;31:411-420, quiz 421

10 Chang EH, Menezes M, Meyer NC, et al. Branchio-oto-renal syndrome: the mutation spectrum in EYA1 and its phenotypic consequences. Hum Mutat 2004;23:582-589
11 Fraser FC, Sproule JR, Halal F. Frequency of the branchio-oto-renal (BOR) syndrome in children with profound hearing loss. Am J Med Genet 1980;7:341-349

12 Ostri B, Johnsen T, Bergmann I. Temporal bone findings in a family with branchio-oto-renal syndrome (BOR). Clin Otolaryngol Allied Sci 1991;16:163-167

13 Kemperman MH, Stinckens C, Kumar S, Huygen PL, Joosten FB, Cremers CW. Progressive fluctuant hearing loss, enlarged vestibular aqueduct, and cochlear hypoplasia in branchio-oto-renal syndrome. Otol Neurotol 2001;22:637-643

14 Stinckens C, Standaert L, Casselman JW, et al. The presence of a widened vestibular aqueduct and progressive sensorineural hearing loss in the branchio-oto-renal syndrome. A family study. Int J Pediatr Otorhinolaryngol 2001;59:163-172

15 Ceruti S, Stinckens C, Cremers CW, Casselman JW. Temporal bone anomalies in the branchio-oto-renal syndrome: detailed computed tomographic and magnetic resonance imaging findings. Otol Neurotol 2002;23:200-207

16 Graham GE, Allanson JE. Congenital cholesteatoma and malformations of the facial nerve: rare manifestations of the BOR syndrome. Am J Med Genet 1999;86:20-26

17 Worley GA, Vats A, Harcourt J, Albert DM. Bilateral congenital cholesteatoma in branchio-oto-renal syndrome. J Laryngol Otol 1999;113:841-843

18 Hernández Montero E, Adiego I, Clau F, Fraile J, Llorente E, Ortiz García A. Síndrome branquio-oto-renal y colesteatoma congénito. O.R.L.-DIPS. 2003;30:222-225

19 Chen A, Francis M, Ni L, et al. Phenotypic manifestations of branchio-oto-renal syndrome. Am J Med Genet 1995;58:365-370

20 König R, Fuchs S, Dukiet C. Branchio-oto-renal (BOR) syndrome: variable expressivity in a five-generation pedigree. Eur J Pediatr 1994;153:446-450 
21 Stratakis CA, Lin J-P, Rennert OM. Description of a large kindred with autosomal dominant inheritance of branchial arch anomalies, hearing loss, and ear pits, and exclusion of the branchio-otorenal (BOR) syndrome gene locus (chromosome 8q13.3). Am J Med Genet 1998;79:209-214

22 Mosrati MA, Hammami B, Rebeh IB, et al. A novel dominant mutation in SIX1, affecting a highly conserved residue, result in only auditory defects in humans. Eur J Med Genet 2011;54:e484-e488

23 Rana I, Dhawan R, Gudwani S, Bothra R, Mathur NN. Non-inherited manifestation of bilateral branchial fistulae, bilateral pre-auricular sinuses and bilateral hearing loss: a variant of branchio-oto-renal syndrome. Indian J Otolaryngol Head Neck Surg 2005;57:52-54

$24 \mathrm{Ni}$ L, Wagner MJ, Kimberling WJ, et al. Refined localization of the branchiootorenal syndrome gene by linkage and haplotype analysis. Am J Med Genet 1994;51:176-184

25 Abdelhak S, Kalatzis V, Heilig R, et al. A human homologue of the Drosophila eyes absent gene underlies branchio-oto-renal (BOR) syndrome and identifies a novel gene family. Nat Genet 1997; 15:157-164

26 Vincent C, Kalatzis V, Abdelhak S, et al. BOR and BO syndromes are allelic defects of EYA1. Eur J Hum Genet 1997;5:242-246

27 Kumar S, Kimberling WJ, Kenyon JB, Smith RJH, Marres HA, Cremers CWRJ. Autosomal dominant branchio-oto-renal syndrome-localization of a disease gene to chromosome $8 \mathrm{q}$ by linkage in a Dutch family. Hum Mol Genet 1992;1:491-495

28 Ruf RG, Xu PX, Silvius D, et al. SIX1 mutations cause branchio-otorenal syndrome by disruption of EYA1-SIX1-DNA complexes. Proc Natl Acad Sci U S A 2004;101:8090-8095

29 Stockley TL, Mendoza-Londono R, Propst EJ, Sodhi S, Dupuis L, Papsin BC. A recurrent EYA1 mutation causing alternative RNA splicing in branchio-oto-renal syndrome: implications for molecular diagnostics and disease mechanism. Am J Med Genet A 2009; 149A:322-327

30 Rodríguez-Soriano J, Vallo A, Bilbao JR, Castaño L. Branchio-otorenal syndrome: identification of a novel mutation in the EYA1 gene. Pediatr Nephrol 2001;16:550-553

31 Vervoort VS, Smith RJH, O'Brien J, et al. Genomic rearrangements of EYA1 account for a large fraction of families with BOR syndrome. Eur J Hum Genet 2002;10:757-766

32 Ito T, Noguchi Y, Yashima T, Kitamura K. SIX1 mutation associated with enlargement of the vestibular aqueduct in a patient with branchio-oto syndrome. Laryngoscope 2006;116:796-799

33 Sanggaard KM, Rendtorff ND, Kjaer KW, et al. Branchio-oto-renal syndrome: detection of EYA1 and SIX1 mutations in five out of six Danish families by combining linkage, MLPA and sequencing analyses. Eur J Hum Genet 2007;15:1121-1131

34 Kochhar A, Orten DJ, Sorensen JL, et al. SIX1 mutation screening in 247 branchio-oto-renal syndrome families: a recurrent missense mutation associated with BOR. Hum Mutat 2008;29:565

35 Krug P, Moriniere V, Marlin S, et al. Mutation screening of the EYA1, SIX1 and SIX5 genes in a large cohort of patients harboring branchio-oto-renal syndrome calls into question the pathogenic role of SIX5 mutations. Hum Mutat 2011;32:183-190

36 Nie X, Sun J, Gordon RE, Cai CL, Xu PX. SIX1 acts synergistically with TBX18 in mediating ureteral smooth muscle formation. Development 2010;137:755-765

37 Gutierrez CB, Bardají C, Bento L, Martinez MA, Conde J. Branchiooto-renal syndrome: incidence in three generations of a family. J Pediatr Surg 1993;28:1527-1529

38 Millman B, Gibson WS, Foster WP. Branchio-oto-renal syndrome. Arch Otolaryngol Head Neck Surg 1995;121:922-925

39 Weber KM, Kousseff BG. New' manifestations of BOR syndrome. Clin Genet 1999;56:306-312

40 Johnston DR, Whittemore K, Poe D, Robson CD, Perez-Atayde AR. Diagnostic and surgical challenge: middle ear dermoid cyst in
12 month old with branchio-oto-renal syndrome and multiple middle-ear congenital anomalies. Int J Pediatr Otorhinolaryngol 2011;75:1341-1345

41 Preisch JW, Bixler D, Ellis FD. Gustatory lacrimation in association with the branchio-oto-renal syndrome. Clin Genet 1985; 27:506-509

42 Bellini C, Piaggio G, Massocco D, et al. Branchio-oto-renal syndrome: a report on nine family groups. Am J Kidney Dis 2001; 37:505-509

43 Misra M, Nolph KD. Renal failure and deafness: branchio-oto-renal syndrome. Am J Kidney Dis 1998;32:334-337

44 Prabhu NT, Alexander S, John R. Branchio-oto-renal syndrome with generalized microdontia: case report. Oral Surg Oral Med Oral Pathol Oral Radiol Endod 1999;87:180-183

45 Ayçiçek A, Sağlam H, Koçoğullari CU, Haktanir NT, Dereköy FS, Solak M. Mitral valve prolapse as a new finding in branchio-otorenal syndrome. Clin Dysmorphol 2010;19:181-184

46 Pierides AM, Athanasiou Y, Demetriou K, Koptides M, Deltas CC. A family with the branchio-oto-renal syndrome: clinical and genetic correlations. Nephrol Dial Transplant 2002;17:1014-1018

47 Garg A, Wadhera R, Gulati SP, Kumar A. Branchio-oto-renal syndrome. J Assoc Physicians India 2008;56:904-905

48 Nardi E, Palermo A, Cusimano P, Mulè G, Cerasola G. Young woman with branchio-oto-renal syndrome and a novel mutation in the EYA-1 gene. Clin Nephrol 2011;76:330-333

$49 \mathrm{Kim} \mathrm{SH}$, Shin JH, Yeo CK, et al. Identification of a novel mutation in the EYA1 gene in a Korean family with branchio-oto-renal (BOR) syndrome. Int J Pediatr Otorhinolaryngol 2005;69: 1123-1128

50 Senel E, Kocak H, Akbiyik F, Saylam G, Gulleroglu BN, Senel S. From a branchial fistula to a branchiootorenal syndrome: a case report and review of the literature. J Pediatr Surg 2009;44:623-625

51 Furlan RH, Rossi NF, Cardoso ACV, Richieri-Costa A, Motonaga SM, Giacheti CM. Achados genéticos, audiológicos e da linguagem oral de um núcleo familial com diagnóstico da síndrome Branquio-otorenal (SBOR). Paper presented at: XVI Congresso Brasileiro de Fonoaudiologia; September 24-27, 2008; Campos do Jordão, São Paulo, Brasil

52 Jankauskienė A, Azukaitis K. Congenital unilateral facial nerve palsy as an unusual presentation of BOR syndrome. Eur J Pediatr 2013;172:273-275

53 Kemperman MH, Koch SM, Kumar S, Huygen PL, Joosten FB, Cremers CW. Evidence of progression and fluctuation of hearing impairment in branchio-oto-renal syndrome. Int J Audiol 2004; 43:523-532

54 Usami S, Abe S, Shinkawa H, Deffenbacher K, Kumar S, Kimberling WJ. EYA1 nonsense mutation in a Japanese branchio-oto-renal syndrome family. J Hum Genet 1999;44:261-265

55 Bamiou DE, Phelps P, Sirimanna T. Temporal bone computed tomography findings in bilateral sensorineural hearing loss. Arch Dis Child 2000;82:257-260

56 Kameswaran M, Kumar RSA, Murali S, Raghunandhan S, Karthikeyan K. Cochlear implantation in branchio-oto-renal syndromea surgical challenge. Indian J Otolaryngol Head Neck Surg 2007; 59:280-283

57 Klingebiel R, Bockmühl U, Werbs M, et al. Visualization of inner ear dysplasias in patients with sensorineural hearing loss. Acta Radiol 2001;42:574-581

58 Kemperman MH, Koch SM, Joosten FB, Kumar S, Huygen PL, Cremers CW. Inner ear anomalies are frequent but nonobligatory features of the branchio-oto-renal syndrome. Arch Otolaryngol Head Neck Surg 2002;128:1033-1038

59 Propst EJ, Blaser S, Gordon KA, Harrison RV, Papsin BC. Temporal bone findings on computed tomography imaging in branchio-otorenal syndrome. Laryngoscope 2005;115:1855-1862 